Prepared for the U.S. Department of Energy under Contract DE-AC05-76RL01830

\title{
MinChem: A Prototype Petrologic Database for Hanford Site Sediments
}
RD Mackley
LA Middleton
GV Last
KJ Cantrell
JA Serkowski

September 2010

\section{Pacific Northwest}

NATIONAL LABORATORY

Proudly Operated by Battelle Since 1965 


\title{
MinChem: A Prototype Petrologic Database for Hanford Site Sediments
}

\author{
RD Mackley \\ GV Last \\ LA Middleton \\ JA Serkowski \\ KJ Cantrell
}

September 2010

Prepared for

the U.S. Department of Energy

under Contract DE-AC05-76RL01830

Pacific Northwest National Laboratory

Richland, Washington 99352 



\section{Summary}

A prototype petrologic database (MinChem) has been under continual development for several years. MinChem contains petrologic, mineralogical, and bulk-rock geochemical data for Hanford Site sediments collected over multiple decades. The database is in relational form and consists of a series of related tables modeled after the Hanford Environmental Information System (HEIS) structures (BHI 2002). The HEIS-compatible tables were created in anticipation of eventual migration into HEIS, or some future form of HEIS (e.g., HEIS-GEO).

There are currently a total of 13,129 results in MinChem from 521 samples collected at 381 different sampling sites. These data come from 19 different original source documents published and unpublished (e.g., letter reports) between 1976 and 2009. The data in MinChem consist of results from analytical methods such as optical and electron microscopy, x-ray diffraction, x-ray fluorescence, and electron probe microanalysis.

The MinChem database is included as Microsoft ${ }^{\circledR}$ Access ${ }^{\circledR}$ database on the enclosed compact disc (CD). 



\section{Acknowledgments}

The authors would like to acknowledge the contributions of William D. Webber and Bruce A. Williams (CH2M-HILL Plateau Remediation Company, for their technical discussions, direction, and project support. Jeffrey R. Serne and Kenneth M. Krupka (PNNL) provided valuable insight on the analysis methods and interpretation of mineralogical and geochemical data.

We would like to acknowledge express our appreciation for the technical review of Kyle R. Parker, and the text processing and editing support of Meghan Spanner (PNNL). 



\section{Acronyms and Abbreviations}

FY

HEIS

MinChem fiscal year

Hanford Environmental Information System

prototype petrologic database 



\section{Contents}

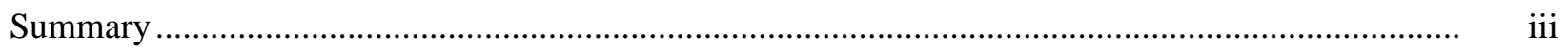

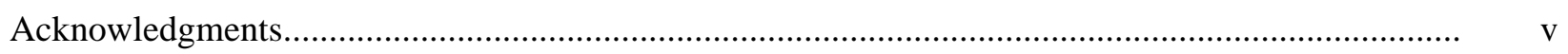

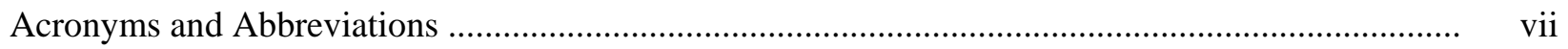

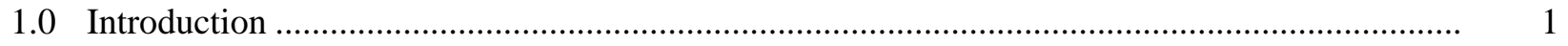

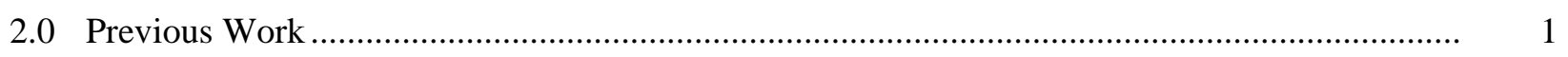

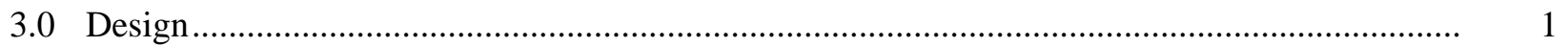

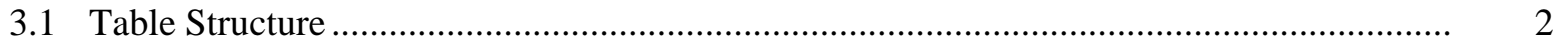

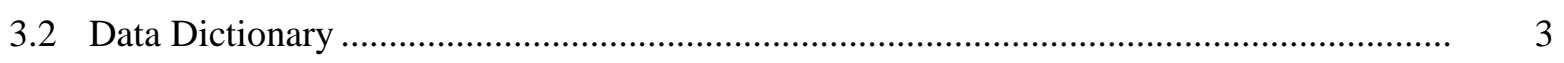

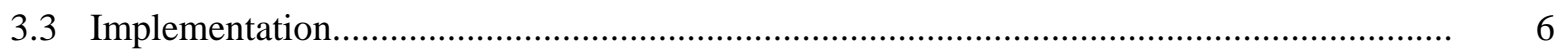

4.0 Data Quality and Review Status ...................................................................................

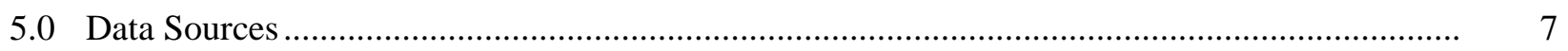

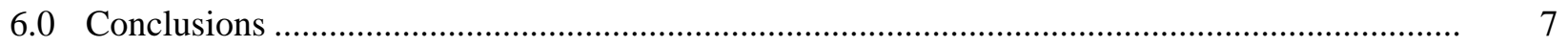

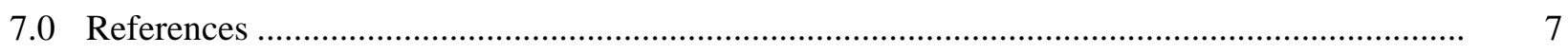

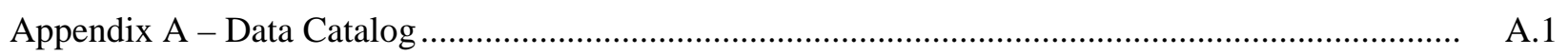




\section{Figures}

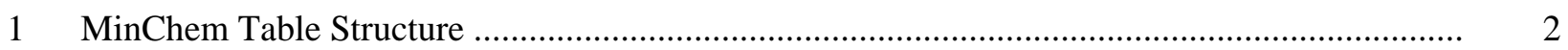

\section{Tables}

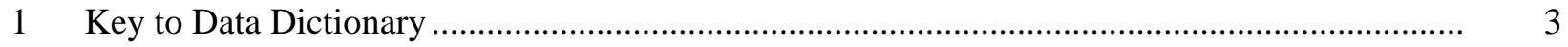

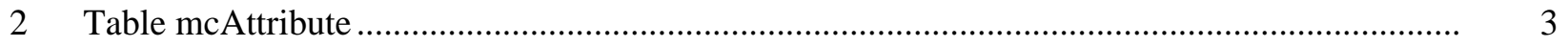

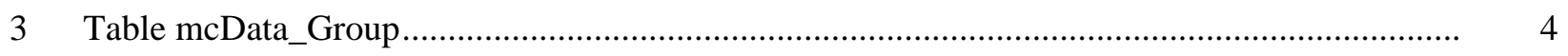

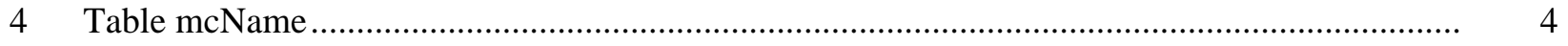

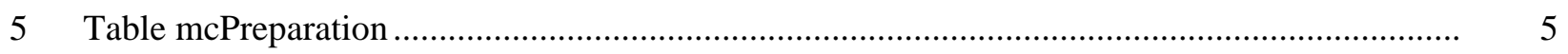

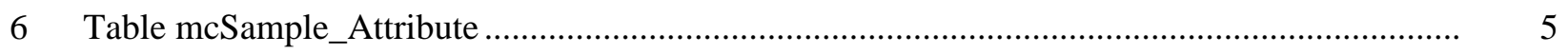

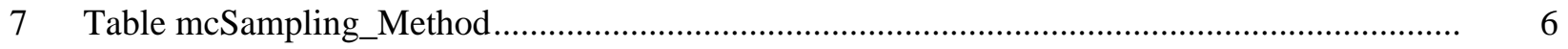

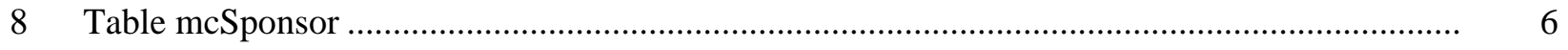




\subsection{Introduction}

A prototype database containing petrologic, mineralogical and bulk-rock geochemical data has been under development since fiscal year (FY) 2008 as part of the Remediation Decision Support Function of the Soil and Groundwater Remediation Project managed by CH2M-HILL Plateau Remediation Company. This database is informally referred to as MinChem. Structural development of MinChem began in FY 2008, and included an initial population of pre-2002 data previously assembled in electronic form (Mackley and Last, 2003). The preliminary data dictionary and data model were documented in a status report at the end of that FY by Mackley et al. (2008). Efforts in FY 2009 and FY2010 have focused on further development of the database structure to ensure consistency and compatibility with the Hanford Environmental Information System (HEIS), as well as on entry and review of additional legacy data (BHI, 2002). This document presents the prototype data model/structure, dictionary of tables and fields, and a summary catalog of available data to date. An implementation of the database described herein is contained in a Microsoft ${ }^{\circledR}$ Access $2007^{\circledR}$ database file (MinChem_09_20_10.accdb), included in the accompanying compact disc.

\subsection{Previous Work}

Petrologic, mineralogical, and bulk-rock geochemical data on geologic material of the Hanford Site have been collected for over 60 years. These data include results from analytical methods such as optical and electron microscopy, x-ray diffraction, $\mathrm{x}$-ray fluorescence, and electron probe microanalysis.

Typically, these data are organized in project-specific and informally-published sources (e.g., hard-copy reports). This information provides a foundation and technical baseline for understanding and defending conceptual models for the geologic framework, geochemical conditions and processes, reactive transport of contaminants, and subsurface remediation. Mackley and Last (2003) and Xie et al. (2003) used multivariate statistical analyses to make formational classifications (e.g., Hanford vs. Ringold formation) based on mineralogy and geochemistry. They recommended the continued collection, management, and use of these data for geological characterization.

Mackley et al. (2008) contains a discussion on the development approach, design requirements and implementation of the prototype petrologic database.

\subsection{Design}

The prototype petrologic database is informally described herein as MinChem. This name is not intended to be permanent. Data in MinChem are stored in 14 normalized tables. The tables are divided into two categories: 1) structural clones of HEIS database tables, and 2) tables exclusive to MinChem. The intent of this division is to make future migration to HEIS as easy as possible. The current relational database software implementation of MinChem is a Microsoft Access 2007 database file (MinChem_09_20_10.accdb), which is included in the accompanying compact disc. 


\subsection{Table Structure}

Figure 1 shows the MinChem table structure. Tables with names including the prefix 'mc' (e.g., mcAttribute) indicate they are specific to MinChem; those with a prefix of 'heis' (e.g., heisResult) are structural clones of existing HEIS tables. The structure centers about the heisSample and heisResult tables, which manage the sample information and analytical result data, respectively. The other tables provide additional information and validation for fields in these two tables where codes are used for brevity. The heisValid_Codes table provides additional field value lookups and is used.

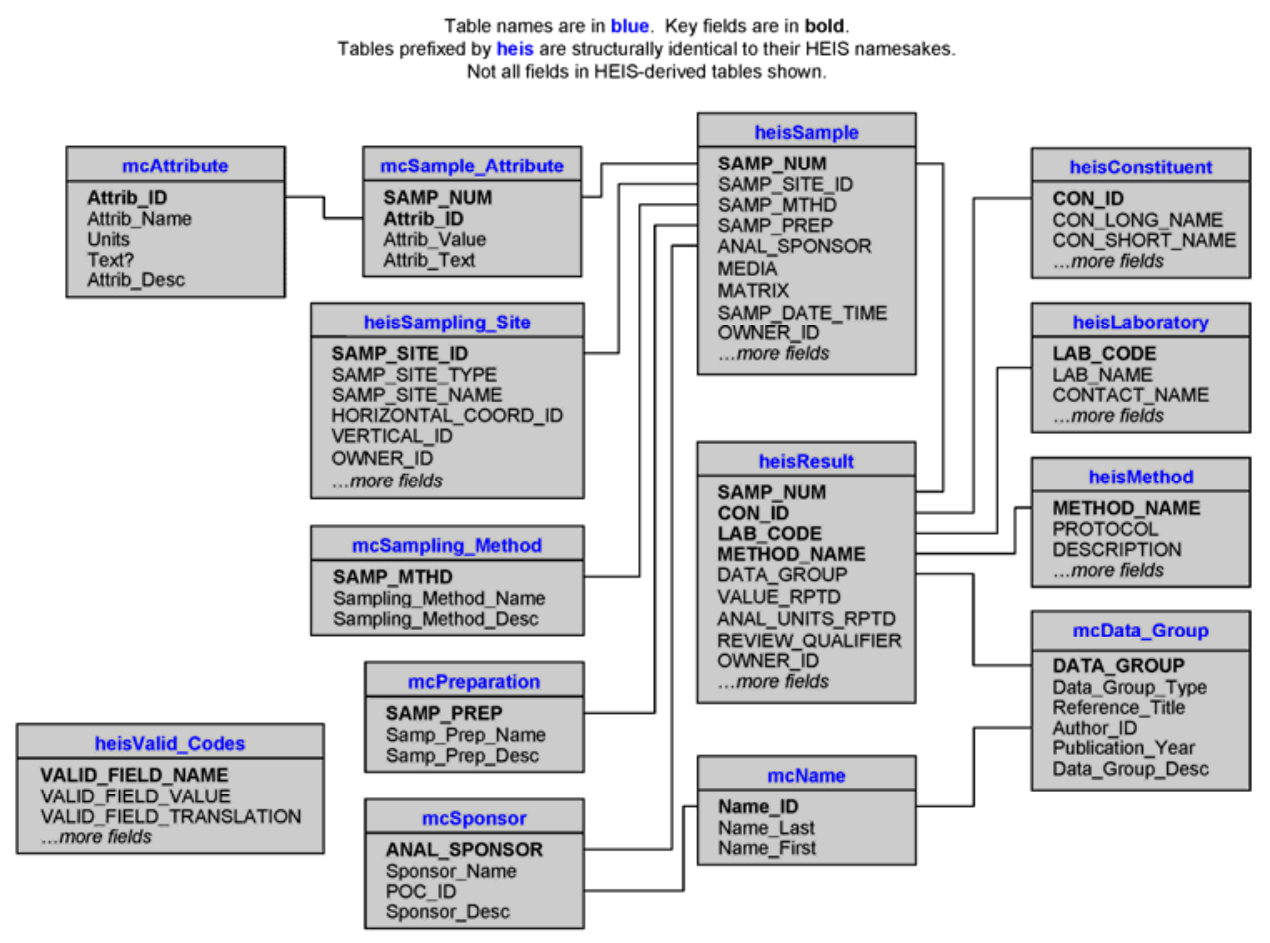

Figure 1. MinChem Table Structure

The mcSample_Attribute table provides a mechanism to attach an indefinite number of attributes to any sample. An attribute can be any numeric or textual value associated with the sample, other than an analysis result. We provide this capability in anticipation of the inevitable pieces of descriptive information that certain projects will find useful but are impossible to predict ahead of time.

The table heisSampling_Site is based on a prototype for a revised version of the existing HEIS SAMPLING_SITE table. Currently, samples in HEIS are associated with either a WELL_NAME or, if not collected from a well, a SAMP_SITE_ID. In this proposed HEIS structure, which has not been formally documented yet, every sample will have a SAMP_SITE_ID associated with it. Moreover, sampling sites may have hierarchical associations with other sampling sites. For example, a sample may be extracted from the deepest few centimeters of a meter-long drill core sample collected from a borehole drilled at a particular waste site. The centimeter-long sampling site is assigned a unique code and described in terms of its location with respect to the drill core. The entire core sample, which may be a meter long, may be assigned to another sampling site that defines the depth range from which the core was obtained in the well. The core is associated with the sampling site for the entire well, and the well, in turn, may be associated with a sampling site defining the area of a waste facility. Thus, the small rock 
sample may be associated to the drill core, the well from which the drill core was extracted, and the waste facility at which the well is located. This permits very powerful location-based queries for samples.

\subsection{Data Dictionary}

Table 1 is an explanation of the fields in the data dictionary tables. Tables 2 through 8 are the data dictionaries for each new MinChem table (those with table names prefixed with 'mc'). Key fields, those that uniquely define a record, are shown in BOLD. The complete data dictionary for the HEIS tables may be found in BHI 2002.

Table 1. Key to Data Dictionary

\begin{tabular}{ll}
\hline \multicolumn{1}{c}{ Column } & \multicolumn{1}{c}{ Description } \\
\hline Contents & Brief description of what is in the table \\
Field & Name of table field \\
Type & Data type of field: $\mathrm{T}=$ text, $\mathrm{N}=$ numeric, I = index (long integer), B = boolean \\
Description & Description of field - contents and limitations \\
Example & Examples of data in this field \\
Lookup & Name of VALID_FIELD_NAME or lookup table if coded field \\
\hline
\end{tabular}

Table 2. Table mcAttribute

\begin{tabular}{|c|c|c|c|c|c|}
\hline Field & Type & Description & Example & $\begin{array}{l}\text { Lookup } \\
\text { Validation }\end{array}$ & Nullable? \\
\hline Attrib_ID & $\mathrm{I}$ & Code for sample attribute name & 1,2 & & NO \\
\hline Attrib_Name & $\mathrm{T}$ & $\begin{array}{l}\text { Unique identifier for the sample } \\
\text { attribute }\end{array}$ & “Size Fraction” & & NO \\
\hline Units & $\mathrm{T}$ & Units of attribute & “Rank”, “\%Vol” & $\begin{array}{l}\text { MC_UNITS } \\
\text { in } \\
\text { heisValid_Cod } \\
\text { es table }\end{array}$ & YES \\
\hline Text? & B & $\begin{array}{l}\text { True if attribute is text; false if } \\
\text { number }\end{array}$ & True, False & & YES \\
\hline Attrib_Desc & $\mathrm{T}$ & Description of attribute & "sample block" & & YES \\
\hline \multicolumn{6}{|c|}{$\begin{array}{l}\text { Contents: Each record is a unique attribute type that may be associated with a sample. Attributes are sample } \\
\text { descriptors for which there is no structure in table heisSample. In particular, attributes are parameters that a user } \\
\text { might wish to use as selection criteria in a query. An attribute can have either a text value or a numeric value, but } \\
\text { not both. }\end{array}$} \\
\hline
\end{tabular}


Table 3. Table mcData_Group

\begin{tabular}{|c|c|c|c|c|c|}
\hline Field & Type & Description & Example & Lookup Validation & Nullable? \\
\hline DATA_GROUP & $\mathrm{T}$ & $\begin{array}{l}\text { Code of form: } \\
\text { MCREFnnnnnnn, } \\
\text { where nnnnnnn is a } \\
\text { unique number. }\end{array}$ & “MCREF0000001" & & $\mathrm{NO}$ \\
\hline Data_Group_Type & $\mathrm{T}$ & $\begin{array}{l}\text { The type of media on } \\
\text { which source data } \\
\text { reside }\end{array}$ & "Document” & $\begin{array}{l}\text { MC_DATA_GROUP_ } \\
\text { TYPE in } \\
\text { heisValid_Codes table }\end{array}$ & NO \\
\hline Reference_Title & $\mathrm{T}$ & $\begin{array}{l}\text { Title of document of } \\
\text { name of file }\end{array}$ & “PNL-7336” & & NO \\
\hline Author_ID & I & $\begin{array}{l}\text { Code for name of } \\
\text { primary author or file } \\
\text { owner }\end{array}$ & 1,2 & $\begin{array}{l}\text { Name_ID field in } \\
\text { mcName table }\end{array}$ & YES \\
\hline Publication_Year & $\mathrm{N}$ & $\begin{array}{l}\text { Year in which } \\
\text { document was public } \\
\text { or file created }\end{array}$ & 1998 & & YES \\
\hline Data_Group_Desc & $\mathrm{T}$ & $\begin{array}{l}\text { Description of } \\
\text { reference }\end{array}$ & “PNNL-17663” & & YES \\
\hline
\end{tabular}

Contents: The data group is a reference to the source of the analysis results. This might be a published document or a computer file.

Table 4. Table mcName

\begin{tabular}{|c|c|c|c|c|c|}
\hline Field & Type & Description & Example & Lookup Validation & Nullable? \\
\hline Name_ID & $\mathrm{I}$ & Unique ID for name & 1,2 & & NO \\
\hline Name_Last & $\mathrm{T}$ & Person’s last name & “Doe” & & NO \\
\hline Name_First & $\mathrm{T}$ & Person's first name & "John" & & YES \\
\hline Initials & $\mathrm{T}$ & Person’s initials & “J.D." & & YES \\
\hline
\end{tabular}

Contents: This table contains the first and last names of people referred to in the database. 
Table 5. Table mcPreparation

\begin{tabular}{|c|c|c|c|c|c|}
\hline Field & Type & Description & Example & $\begin{array}{l}\text { Lookup } \\
\text { Validation } \\
\end{array}$ & Nullable? \\
\hline SAMP_PREP & $\mathrm{T}$ & $\begin{array}{l}\text { Unique short name for } \\
\text { sample preparation }\end{array}$ & “<2 micron” & & $\mathrm{NO}$ \\
\hline Samp_Prep_Name & $\mathrm{T}$ & $\begin{array}{l}\text { Long name for sample } \\
\text { preparation }\end{array}$ & $\begin{array}{l}\text { "Less than } 2 \text { micron size } \\
\text { fraction" }\end{array}$ & & YES \\
\hline Samp_Prep_Desc & $\mathrm{T}$ & $\begin{array}{l}\text { Description of sample } \\
\text { preparation }\end{array}$ & $\begin{array}{l}\text { "Less than } 2 \text { micron size } \\
\text { fraction obtained by } \\
\text { sieving" }\end{array}$ & & YES \\
\hline \multicolumn{6}{|c|}{$\begin{array}{l}\text { Contents: Sample preparation is the modification of a sample between the time it is collected and the time it is } \\
\text { analyzed. There may be some overlap with sample collection and sample analysis, as both these activities may also } \\
\text { modify the sample to some degree, so preparation is reserved for those actions not addressed in the sampling method } \\
\text { or analysis method. Typically, procedures such as sieving, sorting, drying, crushing, etc., are considered sample } \\
\text { preparation. }\end{array}$} \\
\hline
\end{tabular}

Table 6. Table mcSample_Attribute

\begin{tabular}{|c|c|c|c|c|c|}
\hline \multirow[b]{2}{*}{ Field } & \multirow[b]{2}{*}{ Type } & \multirow[b]{2}{*}{ Description } & \multicolumn{3}{|c|}{ Lookup Validation } \\
\hline & & & Example & & Nullable? \\
\hline SAMP_NUM & $\mathrm{T}$ & $\begin{array}{l}\text { Sample number associated with } \\
\text { attribute }\end{array}$ & “MC0000001” & $\begin{array}{l}\text { SAMP_NUM field in } \\
\text { heisSample table }\end{array}$ & NO \\
\hline Attrib_ID & I & Code for sample attribute name & 1,2 & $\begin{array}{l}\text { Attrib_ID field in } \\
\text { mcAttribute table }\end{array}$ & NO \\
\hline Attrib_Value & $\mathrm{N}$ & $\begin{array}{l}\text { Numeric value if attribute type } \\
\text { is Text? = False }\end{array}$ & 3.14 & & YES \\
\hline Attrib_Text & $\mathrm{T}$ & $\begin{array}{l}\text { Text string if attribute type is } \\
\text { Text? = True }\end{array}$ & “sG” & & YES \\
\hline
\end{tabular}

Contents: This table contains attribute data for a sample. An attribute record can have either a text value or a numeric value, but not both. 
Table 7. Table mcSampling_Method

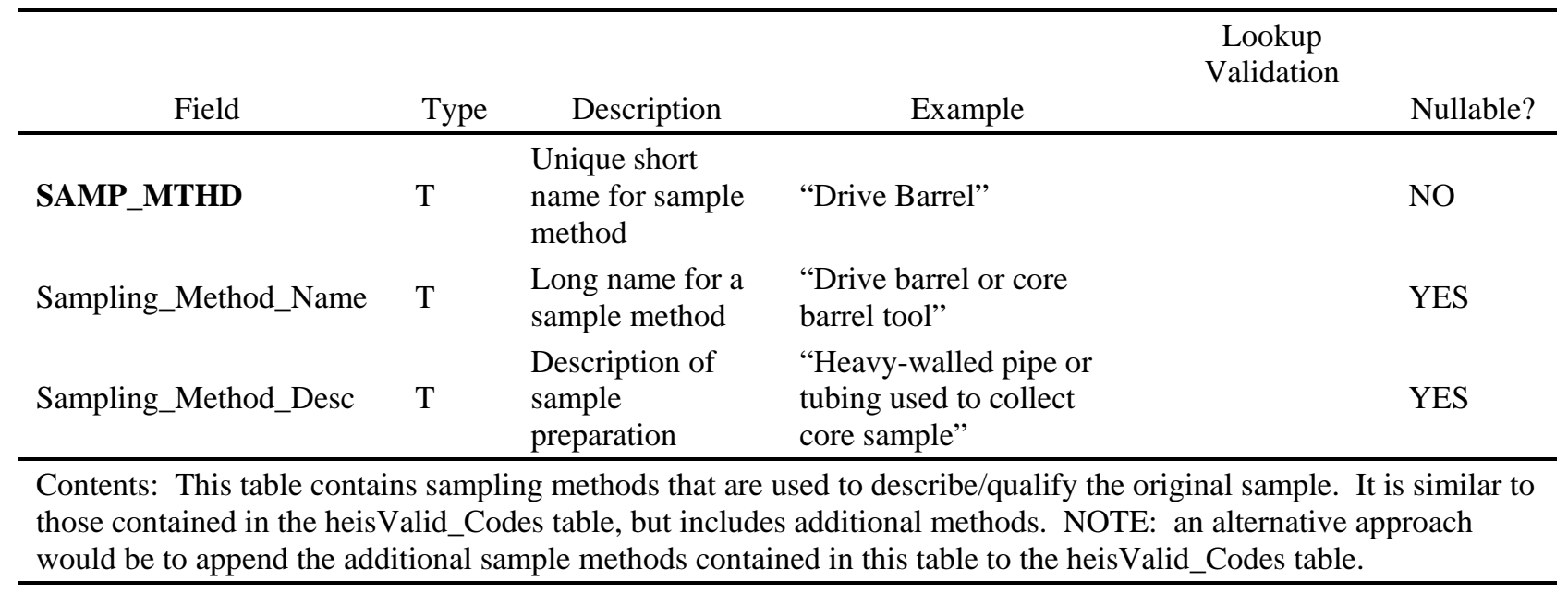

Table 8. Table mcSponsor

\begin{tabular}{|c|c|c|c|c|c|}
\hline Field & Type & Description & Example & Lookup Validation & Nullable? \\
\hline ANAL_SPONSOR & $\mathrm{T}$ & $\begin{array}{l}\text { Code of form: } \\
\text { MCnnnn, where nnnn } \\
\text { is a unique number. }\end{array}$ & "MC0001” & & NO \\
\hline Sponsor_Name & $\mathrm{T}$ & $\begin{array}{l}\text { Descriptive name of } \\
\text { sponsor }\end{array}$ & "BWIP” & & NO \\
\hline POC_ID & I & $\begin{array}{l}\text { ID for sponsor point of } \\
\text { contact }\end{array}$ & 1,2 & $\begin{array}{l}\text { Name_ID field in } \\
\text { mcName table }\end{array}$ & YES \\
\hline Sponsor_Desc & $\mathrm{T}$ & $\begin{array}{l}\text { Description of } \\
\text { sponsoring project }\end{array}$ & "Basalt Waste ..." & & YES \\
\hline
\end{tabular}

Contents: The sponsor is the project associated with the sample. This is usually the funding project. Note: this table has not been fully populated due to the limited information and emphasis at this time. Future efforts should more fully populate this table, as it could be useful.

\subsection{Implementation}

The prototype MinChem table structures and relationships are stored in the Microsoft Access 2007 relational database management system. This software was chosen because it is relatively easy to use, has multi-user capability, interfaces with HEIS, and is widely available to Hanford Site contractors.

Once the necessary MinChem database tables and structures have been incorporated into HEIS, and the prototype database loaded and tested, easy access to the database for all Hanford end users will be implemented. 


\subsection{Data Quality and Review Status}

During the design, implementation, and population of the MinChem database structures, several issues were identified regarding consistency of lab/review qualifiers and compatibility of MinChem with existing HEIS structures. For example, there are results that contain "trace", "less than $(<)$ ", or "not determined" in the reported values from the original source. An effort was made to be consistent with existing HEIS qualifier codes; however the qualifiers entered into the LAB_COMMENT_CD, LAB_QUALIFER, and REVIEW_QUALIFYER fields need to be reassessed for consistency. During FY 2010, the "<” qualifier was added to the LAB_COMMENT_CD field (heisResult table) when the less-than sign preceded a numeric value in the original data source. This was a change to the data-entry process in an effort to improve the ability of MinChem to adequately manage original less-than qualifiers. Prior to this, the "U" qualifier in the LAB_QUALIFIER field was used to denote this. There are similar issues with trace amount qualifiers. A single-consistent method for dealing with trace, less-than, and notdetermined qualifiers (to name a few) needs to be designed and implemented. This quality assurance/quality control process needs to be completed prior to release of the final production database. This will involve going back to the original data sources (which are captured in MinChem) and updating qualifier entries where appropriate. Until then, the data in the prototype database MinChem should be regarded as preliminary and subject to change.

\subsection{Data Sources}

Data entered into the database during fiscal years 2008 through 2010 come from various hard-copy and electronic sources. These are primarily technical reports containing tables of reported analytical results published between 1976 and 2006. Appendix A contains a summary catalog of the documents and the number of accompanying records in the database.

\subsection{Conclusions}

A preliminary database has been developed that will allow petrologic, mineralogical, and bulk-rock geochemical information to be managed under configuration control and facilitate electronic querying. The database is currently developed in Microsoft Access. Each field and table has been described in a data dictionary. The current state of the prototype database reflects the original intent to deliver a HEIScompatible set of tables for the eventual integration into the HEIS system.

\subsection{References}

BHI. 2002. Hanford Environmental Information System - Detailed Design Specification. BHI-01639 Rev. 0, Bechtel Hanford Inc., Richland, Washington. 
Mackley, RD and GV Last. 2003. "Mineralogical and Bulk-Rock Geochemical Signatures of Ringold and Hanford Formation Sediments.” Journal of Undergraduate Research, Office of Science, U.S. Department of Energy, Volume 3, p. 107.

Mackley RD, JA Serkowski, and GV Last. 2008. Status Report on the Creation of a Preliminary Data Model and Dictionary for a New Petrologic Database. PNNL-17663, Pacific Northwest National Laboratory, Richland, Washington.

Xie YL, CJ Murray, GV Last, and RD Mackley. 2003. Mineralogical and Bulk-Rock Geochemical Signatures of Ringold and Hanford Formation Sediments. PNNL-14202, Pacific Northwest National Laboratory, Richland, Washington. 
Appendix A

\section{Data Catalog}





\section{Appendix A}

\section{Data Catalog}

This appendix contains a series of tables that summarize the data in the prototype petrologic database in groupings of data source, well, and "non-well” locations as of 09/20/2010. 
Table A.1. Summary of Available Data From Unique Data Sources Currently Captured in the Petrologic Database (As of 09/20/2010; Ordered by Publication Year)

\begin{tabular}{|c|c|c|c|}
\hline Reference Title & $\begin{array}{c}\text { Sampling } \\
\text { Sites }\end{array}$ & Samples & Results \\
\hline Ames, L. L. 1976. Sediment Mineralogy and Petrology. Task Number C83204. & 18 & 28 & 240 \\
\hline $\begin{array}{l}\text { Tallman, A. M., K. R. Fecht, et al. 1979. Geology of the Seperation Areas, Hanford Site, } \\
\text { South-Central Washington. Rockwell Hanford Operations, Richland, Washington. }\end{array}$ & 42 & 44 & 357 \\
\hline $\begin{array}{l}\text { Schramke, J. A. (1988). Characterization of } 200 \text { Area Soil Samples, Pacific Northwest } \\
\text { Laboratory. }\end{array}$ & 9 & 12 & 96 \\
\hline $\begin{array}{l}\text { Bjornstad, B.N., 1990, Geohydrology of the 218-W-5 Burial Ground, } 200 \text { West Area, } \\
\text { Hanford Site. PNL-7336, Pacific Northwest Laboratories, Richland, Washington. }\end{array}$ & 35 & 43 & 677 \\
\hline $\begin{array}{l}\text { Chamness, M. A., S. P. Luttrell, et al. (1990). 2101-M Pond Hydrogeologic } \\
\text { Characterization Report. Richland, Washington, Pacific Northwest Laboratory. }\end{array}$ & 6 & 6 & 46 \\
\hline $\begin{array}{l}\text { Letter to K.R. Fecht from M.A. Neely, August 20, 1990, "Transmittal of the Remaining } \\
\text { Sediment Analytical Results from RCRA Wells" }\end{array}$ & 152 & 155 & 7,062 \\
\hline $\begin{array}{l}\text { Newcomer, D. R., L.A. Doremus, S.H. Hall, M.J. Truex, V.R. Vermeul, R.E. Engleman. } \\
\text { 1995. Geology, Hydrology, Chemistry, and Microbiology of the In Situ Bioremediation } \\
\text { Demonstration Site. PNL-10422. Pacfic Northwest National Laboratories }\end{array}$ & 6 & 7 & 28 \\
\hline $\begin{array}{l}\text { Wright, J. V., J. L. Conca, et al. 1995. VOC-Arid Site Integrated Demonstration R\&D } \\
\text { Characterization and Monitoring Technologies Subtask } 3 \text { Milestone Report Final Report } \\
\text { of the UFA Technology for Vadose Zone Transport Measurements. }\end{array}$ & 3 & 6 & 27 \\
\hline $\begin{array}{l}\text { Lindberg, J. W., B. A. Williams, and F. A. Spane, 1997. Borehole Data Package for } \\
\text { Well 699-37-47A, PUREX Plant Cribs, CY 1996. PNNL-11515, Pacific Northwest } \\
\text { National Laboratory, Richland, Washington. }\end{array}$ & 1 & 1 & 4 \\
\hline $\begin{array}{l}\text { Mattigod et al. 2000. Mineralogy of Selected Sediments Samples from Borehole 299-E- } \\
\text { 17-21. Letter Report. Pacific Northwest National Laboratory. Richland. }\end{array}$ & 8 & 24 & 128 \\
\hline $\begin{array}{l}\text { Serne, et al. 2002. Characterization of Uncontaminated Vadose Zone Sediment from } \\
\text { the Hanford Reservation - RCRA Borehole Core Samples and Composite Samples. } \\
\text { PNNL-13757-1, Pacific Northwest National Laboratory, Richland, Washington. }\end{array}$ & 17 & 36 & 727 \\
\hline $\begin{array}{l}\text { Serne, et al. 2002. Characterization of Vadose Zone Sediment: RCRA Borehole 299- } \\
\text { E33-338 Located Near the B-BX-BY Waste Management Area. PNNL-14121, Pacific } \\
\text { Northwest National Laboratory, Richland, Washington. }\end{array}$ & 21 & 45 & 1,473 \\
\hline $\begin{array}{l}\text { Serne, et al. 2002. Characterization of Vadose Zone Sediment: Slant Borehole SX-108 } \\
\text { in the S-SX Waste management Area. PNNL-13757-4, Pacific Northwest National } \\
\text { Laboratory, Richland, Washington. }\end{array}$ & 10 & 18 & 89 \\
\hline $\begin{array}{l}\text { Horton et al. 2003. Geochemistry of Samples from Borehole C3177(299-E24-21) } \\
\text { PNNL-14289, Pacific Northwest National Laboratory, Richland, WA. }\end{array}$ & 15 & 27 & 541 \\
\hline $\begin{array}{l}\text { Serne, et al. 2004. Characterization of Vadose Zone Sediments Below the T Tank } \\
\text { Farm: Boreholes C4104, C4105, 299-W10-196 and RCRA Borehole 299-W11-39. } \\
\text { PNNL-14849, Pacific Northwest National Laboratory, Richland, Washington. }\end{array}$ & 10 & 16 & 351 \\
\hline $\begin{array}{l}\text { Serne, et al. 2004. Characterization of Vadose Zone Sediments Below the TX Tank } \\
\text { Farm: Boreholes C3830, C3831, C3832 and RCRA Borehole 299-W10-27. PNNL- } \\
\text { 14594, Pacific Northwest National Laboratory, Richland, Washington. }\end{array}$ & 9 & 10 & 579 \\
\hline $\begin{array}{l}\text { Um and Serne. 2006. Characterization of 200-UP-1 and 200-ZP-1 Operable Unit } \\
\text { Sediments and Batch Adsorption Distribution Coefficients for Contaminants of Concern-- } \\
\text { Fiscal Year } 2006 \text { Progress. PNNL-16102, Pacific Northwest National Laboratory, } \\
\text { Richland, Washington. }\end{array}$ & 3 & 4 & 70 \\
\hline $\begin{array}{l}\text { Um et al. 2005. Characterization of 200-UP-1 Aquifer Sediments and Results of } \\
\text { Sorption-Desorption Tests Using Spiked Uncontaminated Groundwater. PNNL-15502, } \\
\text { Pacific Northwest National Laboratory, Richland, Washington. }\end{array}$ & 14 & 25 & 496 \\
\hline $\begin{array}{l}\text { Um et al. 2009. "The effect of gravel size fraction on selected radionuclides' distribution } \\
\text { coefficient." Journal of Contaminant Hydrology 107(1-2): 82-90. }\end{array}$ & 2 & 14 & 138 \\
\hline Total & 381 & 521 & 13,129 \\
\hline
\end{tabular}


Table A.2. Summary of Available Data for Wells (Boreholes) in the Petrologic Database (As of 09/20/2010)

\begin{tabular}{|c|c|c|c|}
\hline Well Name & $\begin{array}{l}\text { Sample } \\
\text { Sites }\end{array}$ & Samples & Results \\
\hline 299-E13-5 & 1 & 1 & 9 \\
\hline 299-E13-8 & 1 & 1 & 8 \\
\hline 299-E15-21 & 3 & 3 & 123 \\
\hline 299-E16-1 & 2 & 2 & 14 \\
\hline 299-E17-21 & 8 & 24 & 128 \\
\hline 299-E18-1 & 1 & 1 & 4 \\
\hline 299-E18-3 & 5 & 5 & 42 \\
\hline 299-E19-1 & 5 & 5 & 30 \\
\hline 299-E24-19 & 5 & 6 & 304 \\
\hline 299-E24-21 & 15 & 27 & 541 \\
\hline 299-E25-15 & 1 & 2 & 21 \\
\hline 299-E25-40 & 5 & 5 & 255 \\
\hline 299-E25-41 & 5 & 5 & 252 \\
\hline 299-E27-11 & 6 & 6 & 299 \\
\hline 299-E27-12 & 5 & 5 & 243 \\
\hline 299-E27-13 & 5 & 5 & 225 \\
\hline 299-E27-14 & 5 & 5 & 214 \\
\hline 299-E27-15 & 5 & 5 & 250 \\
\hline 299-E27-16 & 5 & 5 & 220 \\
\hline 299-E27-6 & 3 & 3 & 17 \\
\hline 299-E28-22 & 1 & 1 & 6 \\
\hline 299-E28-26 & 2 & 4 & 26 \\
\hline 299-E32-5 & 5 & 5 & 215 \\
\hline 299-E33-201 & 1 & 3 & 30 \\
\hline 299-E33-244 & 2 & 3 & 24 \\
\hline 299-E33-31 & 6 & 6 & 300 \\
\hline 299-E33-32 & 3 & 3 & 130 \\
\hline 299-E33-338 & 21 & 45 & 1,473 \\
\hline 299-E33-36 & 5 & 6 & 257 \\
\hline 299-E33-37 & 5 & 5 & 236 \\
\hline 299-E34-3 & 1 & 2 & 13 \\
\hline 299-E34-7 & 5 & 5 & 250 \\
\hline 299-E35-1 & 4 & 4 & 200 \\
\hline 299-E7-7 & 2 & 2 & 46 \\
\hline 299-W10-13 & 7 & 12 & 178 \\
\hline 299-W10-14 & 3 & 3 & 57 \\
\hline 299-W10-148 & 1 & 6 & 62 \\
\hline 299-W10-15 & 6 & 6 & 258 \\
\hline 299-W10-16 & 6 & 6 & 268 \\
\hline 299-W10-27 & 9 & 10 & 579 \\
\hline 299-W11-10 & 1 & 1 & 8 \\
\hline 299-W11-26 & 7 & 7 & 54 \\
\hline 299-W11-32 & 6 & 7 & 28 \\
\hline 299-W11-39 & 4 & 5 & 295 \\
\hline
\end{tabular}


Table A.2. (cont)

\begin{tabular}{|c|c|c|c|}
\hline Well Name & $\begin{array}{l}\text { Sample } \\
\text { Sites }\end{array}$ & Samples & Results \\
\hline 299-W11-47 & 1 & 1 & 17 \\
\hline 299-W14-8 & 1 & 1 & 7 \\
\hline 299-W15-16 & 7 & 8 & 127 \\
\hline 299-W15-17 & 2 & 2 & 38 \\
\hline 299-W15-19 & 5 & 5 & 250 \\
\hline 299-W15-20 & 6 & 6 & 258 \\
\hline 299-W15-21 & 7 & 7 & 310 \\
\hline 299-W18-174 & 2 & 4 & 19 \\
\hline 299-W18-21 & 5 & 5 & 95 \\
\hline 299-W18-22 & 1 & 4 & 40 \\
\hline 299-W18-26 & 4 & 5 & 227 \\
\hline 299-W18-96 & 1 & 2 & 8 \\
\hline 299-W19-10 & 8 & 21 & 178 \\
\hline 299-W19-48 & 4 & 6 & 136 \\
\hline 299-W22-48 & 8 & 16 & 360 \\
\hline 299-W22-50 & 7 & 14 & 273 \\
\hline 299-W22-87 & 1 & 1 & 18 \\
\hline 299-W23-108 & 1 & 2 & 18 \\
\hline 299-W23-52 & 1 & 2 & 12 \\
\hline 299-W23-72 & 1 & 2 & 20 \\
\hline 299-W7-2 & 5 & 10 & 129 \\
\hline 299-W7-3 & 2 & 4 & 51 \\
\hline 299-W7-5 & 1 & 1 & 19 \\
\hline 299-W7-7 & 12 & 12 & 516 \\
\hline 299-W7-8 & 17 & 17 & 742 \\
\hline 299-W7-9 & 5 & 5 & 214 \\
\hline 699-30-66 & 4 & 7 & 83 \\
\hline 699-36-70B & 6 & 12 & 277 \\
\hline 699-37-47A & 1 & 1 & 4 \\
\hline 699-54-17 & 4 & 4 & 29 \\
\hline C3082 & 10 & 18 & 89 \\
\hline C4105 & 6 & 11 & 56 \\
\hline Total & 350 & 494 & 12,812 \\
\hline
\end{tabular}


Table A.3. Summary of Available Data for the "Non-Well” Point Locations in the Petrologic Database (As of 09/20/2010). Most of these are composite samples.

\begin{tabular}{|c|c|c|c|}
\hline Site & $\begin{array}{c}\text { Sample } \\
\text { Sites }\end{array}$ & Samples & Results \\
\hline 218-E-12B Burial Ground & 1 & 4 & 62 \\
\hline 241-A Tank Farm & 1 & 1 & 8 \\
\hline 241-S Tank Farm & 1 & 1 & 9 \\
\hline 241-SY Tank Farm & 1 & 1 & 12 \\
\hline 241-SY Tank Farm & 1 & 1 & 12 \\
\hline 241-T Tank Farm & 1 & 1 & 9 \\
\hline Integrated Disposal Facility & 1 & 6 & 45 \\
\hline Pit 30 & 1 & 8 & 93 \\
\hline White Bluffs & 1 & 4 & 67 \\
\hline Total & 9 & 27 & 317 \\
\hline
\end{tabular}



PNNL-19803

\section{Distribution}

No. of

Copies

3 Local Distribution

CH2M-HILL Plateau Remediation

Company, Inc.

R Khaleel

WD Webber

BA Williams
No. of

\section{Copies}

10 Local Distribution

Pacific Northwest National Laboratory

BN Bjornstad

K6-81

KJ Cantrell

K6-81

MA Chamness

K9-33

DC Lanigan

K6-75

GV Last

K6-81

RD Mackley (3)

K6-96

LA Middleton

K9-75

KR Parker

K6-96 




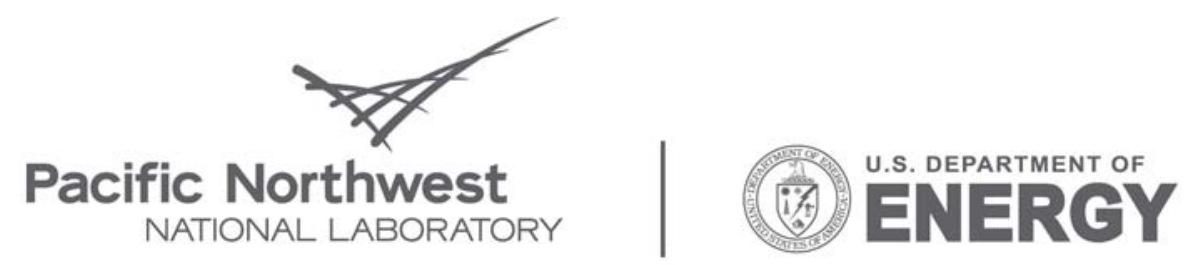

Proudly Operated by Battelle Since 1965

902 Battelle Boulevard

P.O. Box 999

Richland, WA 99352

1-888-375-PNNL (7665)

www.pnl.gov 